\title{
Structural variations of epiphytic diatom communities on three macrophytes in a regulated river (Durance), in South-East of France
}

\author{
K. Comte ${ }^{1}$ \\ A. Cazaubon ${ }^{2}$
}

Keywords : epiphytic diatoms, distribution, submerged macrophytes, Mediterranean river.

The epiphytic diatom communities living on two macroalgae, Chara vulgaris L. and Cladophora glomerata Kütz.) and one angiosperm Potamogeton densus L., were collected in the Mediterranean river Durance. Each macrophyte species was studied on the basis of three plant replicates, each of which cut into three segments. Although considerable heterogeneity was observed in density of the epiphytic populations between the plant species studied as regards, the composition of these algal populations showed a conspicuous degree of homogeneity within each macrophytic species. These observations were corroborated by the coefficients of variation calculated on the main diatoms and by the non parametric Friedman tests.

The qualitative homogeneity of epiphyton on Potamogeton densus foliage made it possible to map the spatial repartition of the main groups of diatoms growing on the upper side of leaves.These data support the hypothesis that the epiphytic algae occupy specific microhabitat niches on their host plants according to a non stochastic pattern of distribution.

Variations structurales des communautés épiphytiques sur trois macrophytes dans une rivière régulée (Durance), du Sud-Est de la France

Mots-clés : diatomées épiphytiques, distribution, hydrophytes, rivière méditerranéenne.

L'étude des communautés de diatomées épiphytiques a été réalisée sur 3 macrophytes ( 2 macroalgues : Chara vulgaris L. et Cladophora glomerata Kütz. et un angiosperme : Potamogeton densus L.) prélevés dans une rivière régulée méditerranéenne du sud-est de la France, la Durance. Chaque espèce a été étudiée à partir de trois échantillons sectionnés chacun en trois parties.

Si une grande hétérogénéité densitaire du peuplement épiphytique a été constatée au niveau interspécifique, une nette homogénéité de la composition algale existe au plan intraspécifique.

Ces observations ont été confirmées par les calculs de coefficient de variation et les tests de Friedman réalisés au niveau de l'inter- et intra-macrophyte. La distribution diatomique relevée sur chaque réplicat de Potamogeton densus a permis de cartographier les différentes catégories d'épiphytes sur la face supérieure des feuilles de ce macrophyte. Ces premiers résultats renforcent l'hypothèse que les répartitions algales ne s'effectuent pas forcément de façon stochastique sur la plante-hôte.

\section{Introduction}

Considerable attention has focused during the last few years on epiphytic algae, which were previously neglected, mainly because they were difficult to

\footnotetext{
1. Institut Pasteur, Unité des Cyanobactéries (CNRS, URA 2172), Département de Microbiologie Fondamentale et Médicale, 28 rue du Docteur Roux, 75724 Paris cedex XV, France.

2. Laboratoire d'Ecologie des Eaux Continentales (CNRS, UMR 6116), Faculté des Sciences de Saint-Jérôme, 13397 Marseille, France.
}

sample. However, epiphytic algal populations are now considered to play an important role in aquatic ecosystems (Wetzel 1983), since they can be highly productive in all water systems, especially in lakes (Cattaneo \& Kalff 1979).

But many questions remain concerning how the algae depends both on its host, itself a dynamic being (Allen 1971, Allanson 1973, Blindow 1987, Burkholer \& Wetzel 1989, 1990) and its environment (Harlin 1973, Cattaneo \& Kalff 1978, 1979, 1980, Fontaine \& Nigh 1983, Millie \& Lowe 1983, Morin 1986). Very few studies on the spatial location of the epiphyton on the host plant have been conducted in situ. This is particularly true for winter periods when important hydro- 
dynamic fluctuations cause the collapse of the macrophyte beds in rivers. However, in many rivers and lakes, the flow rate is artificially regulated by water companies, such as EDF (Electricité de France) in France, and those variations do not occur. The herbarium thus remains constant over the year (Fayolle 1998). This unnatural but frequent situation allows the study of the epiphytic algae on a stable macrophytic host during the winter resting period. The macrophyte could stand as an additional substratum for the algae when the rocks are unreachable due to the depth of the river. The issue is the study of the epiphyton population as a potential indicator of water quality controls (Kelly et al. 1998, Lenoir \& Coste 1994).

The present study concerns the Durance, a regulated river located in the South East of France and has focused on 3 macrophytes during winter 1998. All the samples have been chosen and collected with the same morphological criteria. This permits a qualitative and quantitative comparison of the «true» epiphyton with firmly attached algae (Goldsborough 1986, Round 1981, Snoeijs 1994) both at the between-species and between-plants level.

By investigating the microhabitat provided by each plant, it was then proposed to assess the variability of the main diatom species associated with each part of the plant and to develop a model accounting in particular for the distribution of the main epiphytes inhabiting the upper faces of Potamogeton densus foliage.

\section{Description of the studied site}

The river Durance, flowing in the southern Alps, is $350 \mathrm{~km}$ long, and is the main tributary of the river Rhône. From 1956 onwards, it has been part of a large-scale hydro-electric scheme, which has greatly changed its hydrological regime in the middle and lower parts of its course. Most of the flow goes through a concrete channel (at a rate of 150 to $250 \mathrm{~m}^{3} \cdot \mathrm{s}^{-1}$ ), whereas the compensation flow going via the natural bed amounts to only 1.5 to $3 \mathrm{~m}^{3} . \mathrm{s}^{-1}$. The sampling site is located in the natural river bed, downstream from the artificial basin (Fig. 1), near a shallow basin (150 m long, $70 \mathrm{~m}$ wide, maximum depth $1.8 \mathrm{~m}$ ) designed to regulate the water flowing from the dam turbines. Due to the slowness of the current $\left(10-30 \mathrm{~cm} . \mathrm{s}^{-1}\right)$, a layer of sediment several $\mathrm{cm}$ thick was deposited there, in which three different stands of macrophytes (according to Holmes \& Whitton 1977) were growing separately. One singlespecies stand of Chara vulgaris L. var. foetida (Vaillant) had developed on the North bank of the basin at a depth of -1-1.2 m, covering an area of about
$2500 \mathrm{~m}^{2}$ (Fayolle et al. 1998). A second stand, consisting of Potamogeton densus L., was covering an area of $1400 \mathrm{~m}^{2}$ on the South bank of the basin at a depth of - 0.9 - $1.2 \mathrm{~m}$. Lastly, a stand of Cladophora glomerata Kütz. was developing on the rough limestone substrates at the outlet of the shallow basin, at a depth of $-0.50 \mathrm{~m}$.

\section{Material and methods}

The sampling was done in December 1998, when the growth of Potamogeton densus stands are reduced. In this regulated river, Chara vulgaris has a constant standing crop all the year, and the two macrophytes become perennial (Fayolle 1998). All the plants were collected under similar conditions (Comte 1996). The replicates have the same morphology and height and live at the same depth with equal hydrodynamic disturbance:

The upper edges of their respective stands is previously chosen in order to reduce any artefacts which might have been caused by the lack of light at the centre and by the frequent inter-plant friction. They were placed immediately in separate bags and treated with neutral formaldehyde (\%).

Because of the height of the plants, each sample was consistently cut up as follows.

Three pieces $1 \mathrm{~cm}$ in length (Surface area : $21 \mathrm{~cm}^{2}$ ) of $C$. vulgaris were cut at the apical, middle and base parts ( $5 \mathrm{~cm}$ up from the sediment) of the macroalgae.

Potamogeton densus was also cut up into several pieces, each consisting of $0.5 \mathrm{~cm}$ of stalk and a pair of leaves $\left(35 \mathrm{~cm}^{2}\right.$ of surface). The two leaves on segment were analysed separately. The samples were taken at the apical, median and basal parts of each plant.

Lastly, three segments of Cladophora glomerata (covering a surface of $12 \mathrm{~cm}^{2}$ ) were respectively sampled at the apical, median and basal parts (near the point of anchorage to the substrate) of the filamentous algae.

The leaf surface is scratched and estimated as a comparable geometric shape, e.g. a tubular surface for Chara and Cladophora, or a plane surface for the leaves of Potamogeton (Comte 1996).

\section{- Epiphyton}

The microscopy counts and determination are performed on the «true» epiphyton (Goldsborough 1986), that is, the algae bound to its host. Before observation, each sample is washed smoothly with distilled water so as to get rid of the algae laid on the leaf. 


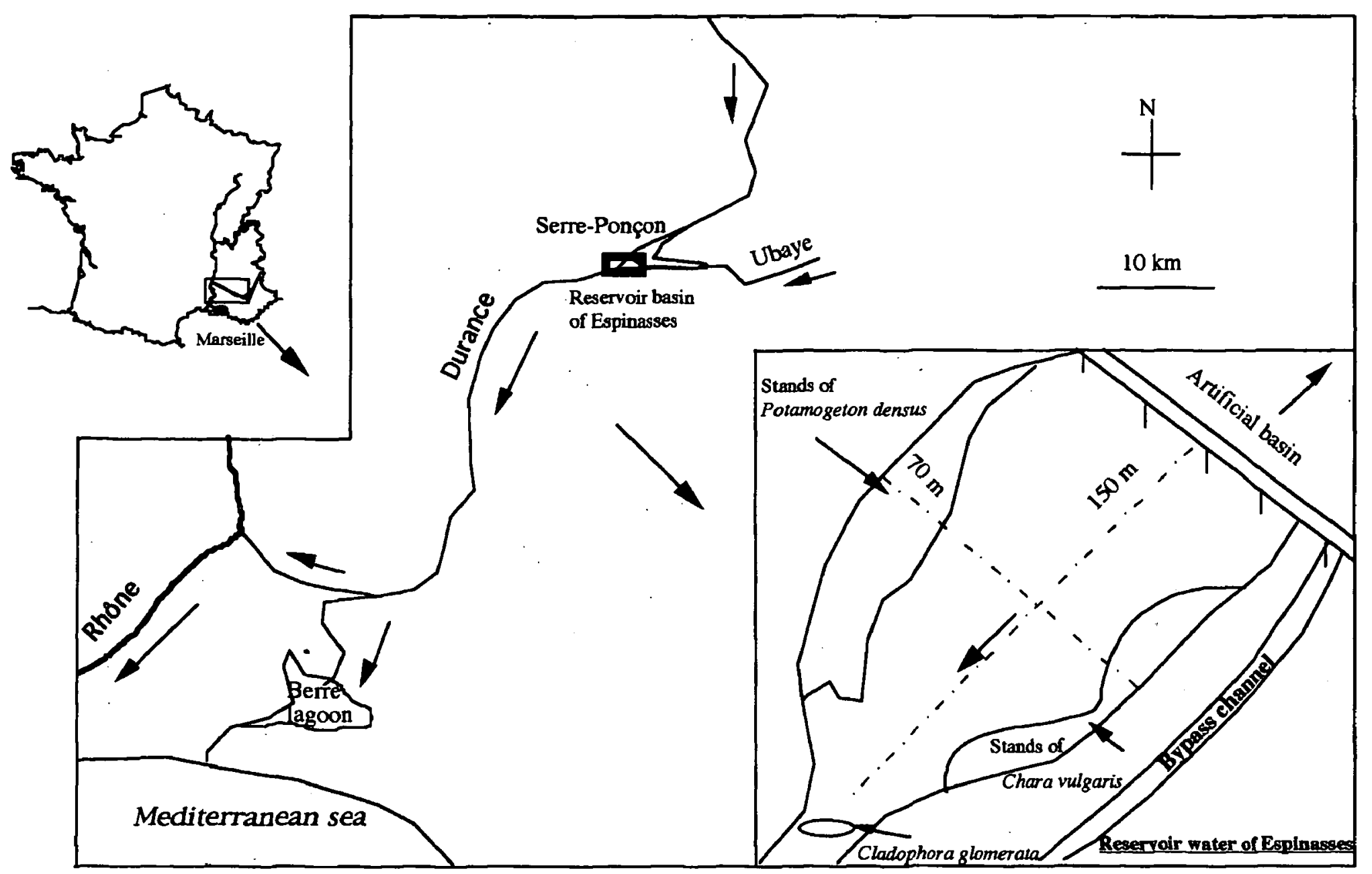

Fig. 1. The study area.

Fig. 1. La station d'étude

Depending on the plant, 2 different techniques of extraction were used : for Chara and Potamogeton, mechanical scratching with a toothbrush (medium-hard); for Cladophora, sonication in hot saline solution (58\%o) to destroy protein mucilage of algae. Counting before and after treatment on a randomly chosen surface permits the assessment of the best method.

The algae are then laid on a grid and counted under the X100 objective (with specific oil) of an Olympus microscope. Diatoms were analysed after destroying all organic matter with $\mathrm{H}_{2} \mathrm{O}_{2}$ and heat (during $8 \mathrm{~h}$ ). The taxa were identified with the SüBwasserflora (Krammer \& Lange-Bertalot 1986, 1988, 1991 a and b). The cell densities were expressed as the number of cells per $\mathrm{cm}^{2}$ plant surface. The morphological stability of the host Potamogeton densus helps the cartography of the epiphyte and the between-plant comparison.

\section{- Statistics}

The means, standard deviations and coefficients of variation ( $\mathrm{s} / \mathrm{mean})$ of the total diatom populations recorded on all replicates made it possible to assess the variability of the composition of epiphytes present on the various substrates. Between-plant comparisons and within-plant comparisons from the density of the diatoms were made by performing a non parametric multiple comparison test of Friedman with dependant and multiple data $>3$. (Friedman 1954). These tests were carried out using the Statview 4.5 software programs.

\section{Results}

- Between-plant variations in the epiphytic communities

The relative abundance of epiphytes (Table 1) is the result of the average counting for each segment of the macrophyte $(A, B, C)$ on three randomly chosen replicates.

The number of true epiphytes is low and corresponds to 15 to 17 different species.

The two most abundant species are the same for Potamogeton and Cladophora, whereas Achnanthes mi- 
Table 1. Taxonomic composition and relative abundance (\%) of the epiphytic diatoms obtained on the 3 samples of each macrophyte. Tableau 1. Liste floristique et abondance relative (\%) des diatomées épiphytiques relevées sur les 3 réplicats de chaque macrophyte.

\begin{tabular}{|c|c|c|c|}
\hline Diatoms & $\begin{array}{c}\text { Potamogeton } \\
\text { densus } \\
\text { leaves and } \\
\text { stems }\end{array}$ & $\begin{array}{c}\text { Chara } \\
\text { vulgaris } \\
\text { internodes }\end{array}$ & $\begin{array}{l}\text { Cladophora } \\
\text { glomerata } \\
\text { flaments }\end{array}$ \\
\hline Achnanthes minutissima Kütz. AMIN & 32 & 24 & $\overline{19,1}$ \\
\hline Achnanthes bioretii Germain $\mathrm{ABIO}$ & 0,1 & & \\
\hline Cocconeis pediculus Ehrbg. CPED & 61 & 2,1 & 40 \\
\hline Cocconeis placentula Ehrbg. CPLA & 1,7 & 0,5 & 3,5 \\
\hline Cyclotella radiosa (Grun.) Lemm. CYRA & & 0,5 & 0,8 \\
\hline Cyclotella sp. CYSP & & 0,1 & \\
\hline Cymbella cistula (Ehrbg.)Kirchner CCIS & & 0,2 & \\
\hline Cymbella leptoceros (Ehrbg.) Kütz. CLEP & & 0,3 & \\
\hline Cymbella minuta Hilse CMIN & 0,1 & & 0,8 \\
\hline Cymbella sp. CYMS & & 0,2 & \\
\hline Denticula tenuis Kuitz. DTEN & & 0,5 & 1 \\
\hline Diatoma tenuis Agardh DITE & & 5 & 2,5 \\
\hline Diatoma vulgaris Bory DVUL & 0,5 & & 15 \\
\hline Epithemia argus (Ehrbg.) Kütz. EARG & & 13 & \\
\hline Fragilaria ulna (Nitzsch.) Lange-Bertalot FULN & 0,1 & 01 & 14 \\
\hline $\begin{array}{l}\text { Gomphonema acuminatum (Ehrbg.) GACU } \\
\text { Gomphonema angustum Agardh GTUM }\end{array}$ & 3 & $\begin{array}{l}0,1 \\
\mathbf{5 2}\end{array}$ & 1,4 \\
\hline Gomphonema olivaceum (Horn.)Brebisson GOLI & 0,2 & 0,5 & 6 \\
\hline Gomphonema truncatum Ehrbg. GTRU & & 1 & 4,6 \\
\hline Gyrosigma attenuatum (Kütz.)Robb. GYAT & 0,1 & & \\
\hline Melosira varians Agardh MVAR & & & 2 \\
\hline Navicula cryptocephala Kütz. NCRY & 0,1 & & \\
\hline Navicula tripunctata (Müller) Bory NTRI & 0,2 & & 1,9 \\
\hline Nitzschia clausii Hantzsch NICL & 0,1 & & \\
\hline Nitzschia dissipata (Kütz.) Grunow NDIS & 0,1 & & 0,8 \\
\hline Nitzschia linearis (Agardh)W.Smith NLIN & 0,1 & & \\
\hline Nitzschia palea (Kütz.)W.Smith NPAL & 0,1 & & \\
\hline Rhoiscophenia abbreviata (Agardh) Lange-Bertalot RABB & 0,5 & & \\
\hline Surirella sp. SUSP & 17 & 15 & $\begin{array}{l}0,5 \\
15\end{array}$ \\
\hline Total taxonomic abundance & & & \\
\hline
\end{tabular}

nutissima is the only species that prevails on the three plants (Cocconeis pediculus being replaced by Gomphonema angustum on Chara).

The relative abundance of secondary species $(>2 \%$ of the total community) and accompanying species $(<2 \%)$ is different in the three plants (Fig. 2, Table 2).

For Chara, only two secondary species and 11 accompanying species are found, these rare algae representing a very low percentage of the population (Table 2).

A similar pattern for Potamogeton consists of one secondary species (Gomphonema angustum : $3 \%$ ), the rest being exclusively accompanying species (14 species accounting for $4 \%$ of total epiphyton). As shown in the figure 2 , the patterns observed for each of the macrophyte highlight the colonizing similarity of the three categories of algae for Chara and Potamogeton.
For Cladophora, the two dominant species are less abundant ( $50 \%$ of population) compared to secondary species $(33.7 \%)$ and accompanying species $(7.2 \%)$.

Between-plant multiple comparison tests of Friedman confirm these differences (Table 3). Indeed, the average density of epiphyte for Cladophora is significantly 100 times smaller than that of the two other plants.

The data in table 3 shows that both total density and prevailing species vary significantly depending on the macrophyte $(p<0.001)$.

As for the accompanying species, no significant difference is noticed between the macrophytes ( $p>0.05$ ). As suspected from the microscopic survey, this may be explained by variations within the individual rather than within the macrophytes. 


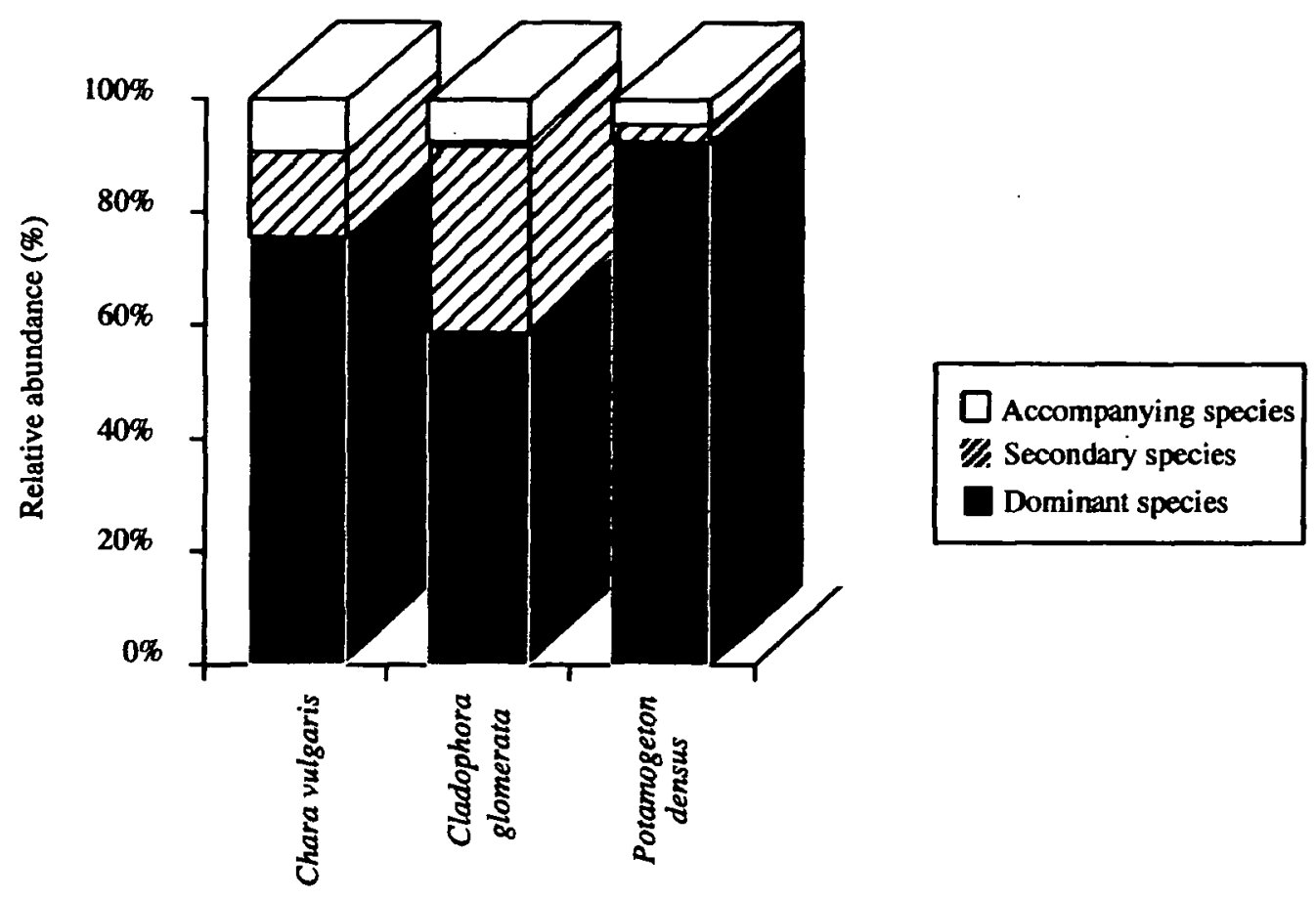

Fig. 2. Comparison of relative abundance (\%) of the 3 epiphytic groups growing on each macrophyte.

Fig. 2. Comparaison de l'abondance relative (\%) des 3 catégories d'épiphytes relevées sur chaque macrophyte. nities

Within-plant variations in the epiphytic commu-

Whatever the macrophyte, the cutting in three parts (apical, medial, and proximal) of the plant does not permit to assess a significant difference $(p>0.05)$ of algal groups (see Table 4). Indeed, huge densities of colonizing cells can be observed both at the apical end, which is the youngest, and on the oldest part of the plant close to the sediments. The age of the plant and the depth of the water column do not seem to affect the algal distribution.

Nevertheless, the values of the coefficient of variation are different depending on the algae, the macrophyte and the fragment of the plant.

The density of the prevailing species is very stable, especially for Chara and Potamogeton variation coefficient, and this is true whatever the fragment of the plant. As for the secondary and accompanying species, the variation coefficient varies tremendously, which shows that no clear distribution for the quantity and category of algae can be demonstrated. The coefficient values are always higher for Cladophora, which confirms an important heterogeneity of epiphytic populations, including the two dominant species (values: 0.5 to 1 ).
- Distribution of epiphyton on Potamogeton den-

The homogenous distribution of the two dominant species and the other algae (including the two other groups) on the leaves (9 replicates) of Potamogeton, allows the cartography of the sites favouring the epiphyton colonization (Fig. 3).

The apex of the leaves is covered with a population almost entirely dominated by the species Cocconeis pediculus, with the interstices occupied by Achnanthes minutissima. The both species inhabit the edges, along with some Gomphonema angustum. Large areas of tissue in the centre of the leaves carry only sparse populations consisting mainly of Cocconeis pediculus, and a few Gomphonema angustum are scattered over the first half of the leaf. On the last third of the leaf stalk, Cocconeis become rare and is replaced by a whole range of accompanying species, less tightly bound to the substratum by the apical end of the hypovalve. As one gets nearer the insertion point of the petiole, the other algae, previously sparse, become more frequently found (Fig. 3).

\section{Discussion}

The results of the present study show that the composition and the density of the epiphytic populations 
Table 2. Composition of the 3 epiphytic groups growing on each macrophyte.

Tableau 2. Caractéristiques des 3 catégories d'épiphytes relevées sur chaque macrophyte.

\begin{tabular}{|c|c|c|c|c|c|c|c|c|}
\hline & \multicolumn{2}{|c|}{ Dominant species } & \multicolumn{3}{|c|}{ Secondary species } & \multicolumn{3}{|c|}{ Accompanying species } \\
\hline & Species & $\begin{array}{l}\text { Relative } \\
\text { abundance } \\
(\%)\end{array}$ & Species & $\begin{array}{l}\text { Relative } \\
\text { abundance } \\
(\%)\end{array}$ & $\begin{array}{l}\text { Specific } \\
\text { richness }\end{array}$ & Species & $\begin{array}{l}\text { Relative } \\
\text { abundance } \\
(\%)\end{array}$ & $\begin{array}{l}\text { Specific } \\
\text { richness }\end{array}$ \\
\hline $\begin{array}{l}\text { Chara } \\
\text { vulgaris }\end{array}$ & $\begin{array}{l}\text { AMNN } \\
\text { GTUM }\end{array}$ & 76 & $\begin{array}{l}\text { EARG } \\
\text { CPED }\end{array}$ & 15.1 & 2 & $\begin{array}{l}\text { CPLA } \\
\text { CRAD } \\
\text { CYCL } \\
\text { CCIS } \\
\text { CLEP } \\
\text { CYSP } \\
\text { DITE } \\
\text { GACU } \\
\text { GOLI } \\
\text { GTRU }\end{array}$ & 8.9 & 10 \\
\hline $\begin{array}{l}\text { Cladophora } \\
\text { glomerata }\end{array}$ & $\begin{array}{l}\text { CPED } \\
\text { AMIN }\end{array}$ & 59.1 & $\begin{array}{l}\text { DVUL } \\
\text { CPLA } \\
\text { DITE } \\
\text { GOLI } \\
\text { GTRU } \\
\text { MVAR }\end{array}$ & 33.7 & 6 & $\begin{array}{l}\text { CMIN } \\
\text { CYRA } \\
\text { DTEN } \\
\text { GACU } \\
\text { NTRI } \\
\text { NDISS } \\
\text { SUSP }\end{array}$ & 7.2 & 7 \\
\hline $\begin{array}{l}\text { Potamogeton } \\
\text { densus }\end{array}$ & $\begin{array}{l}\text { CPED } \\
\text { AMIN }\end{array}$ & 93 & GTUM & 3 & $\mathbf{1}$ & $\begin{array}{l}\text { ABIO } \\
\text { CPLA } \\
\text { CMIN } \\
\text { DVUL } \\
\text { FULN } \\
\text { GOLI } \\
\text { GYAT } \\
\text { NCRY } \\
\text { NTRI } \\
\text { NICL } \\
\text { NDISS } \\
\text { NILI } \\
\text { NPAL } \\
\text { RABB }\end{array}$ & 4 & 14 \\
\hline
\end{tabular}

Table 3. Between-plant heterogeneity : mean and $\mathrm{X}^{2}$ of cell densities (no. of cells./ $\mathrm{cm}^{2}$ ) belonging to the 3 algal groups : dominant, secondary and accompanying species on 3 replicates of each macrophyte (9 samples). Data analysed using the Friedman test $(\mathrm{P}<0.001 ; \mathrm{p}<0.01 ; \mathrm{p}<0.05=$ Significant differences, NS = no difference).

Table 3. Hétérogénéité inter-plante : moyenne et $\mathrm{X}^{2}$ des densités cellulaires (nombre de cellules. $\mathrm{cm}^{-1}$ ) des 3 catégories d'épiphytes : espèces dominantes, secondaires et accompagnatrices sur les 3 réplicats de chaque macrophyte ( 9 échantillons). Données analysées par le test de Fried$\operatorname{man}(\mathrm{P}<0.001 ; \mathrm{p}<0.01 ; \mathrm{p}<0.05=$ Différences significatives, $\mathrm{NS}=$ Aucune différence $)$.

\begin{tabular}{|c|c|c|c|c|c|c|c|c|c|c|c|c|}
\hline & \multicolumn{3}{|c|}{ Total density } & \multicolumn{3}{|c|}{ Dominant species } & \multicolumn{3}{|c|}{ Secondary species } & \multicolumn{3}{|c|}{ Accompanying species } \\
\hline & $\begin{array}{l}\text { Chara } \\
\text { vulgaris }\end{array}$ & $\begin{array}{l}\text { Cladophora } \\
\text { glomerata }\end{array}$ & $\begin{array}{l}\text { Potamogeton } \\
\text { densus }\end{array}$ & $\begin{array}{l}\text { Chara } \\
\text { vulgaris }\end{array}$ & $\begin{array}{l}\text { Cladophora } \\
\text { glomerata }\end{array}$ & $\begin{array}{l}\text { Potamogeton } \\
\text { densus }\end{array}$ & $\begin{array}{l}\text { Chara } \\
\text { vulgaris }\end{array}$ & $\begin{array}{l}\text { Cladophora } \\
\text { glomerata }\end{array}$ & $\begin{array}{l}\text { Potamogeton } \\
\text { densus }\end{array}$ & $\begin{array}{l}\text { Chara } \\
\text { vulgaris }\end{array}$ & $\begin{array}{l}\text { Cladophora } \\
\text { glomerata }\end{array}$ & $\begin{array}{l}\begin{array}{l}\text { Potamogeton } \\
\text { densus }\end{array} \\
\end{array}$ \\
\hline \multirow{2}{*}{$\begin{array}{l}\text { Mean } \\
\text { n } \\
\text { samples }\end{array}$} & \multirow[t]{2}{*}{$1.4210^{5}$} & $6.5710^{3}$ & \multirow[t]{2}{*}{$9.8410^{4}$} & \multirow[t]{2}{*}{$1.0810^{5}$} & $3.8810^{3}$ & \multirow[t]{2}{*}{$9.1510^{4}$} & \multirow[t]{2}{*}{$2.1410^{4}$} & $2.2110^{3}$ & \multirow[t]{2}{*}{$2.9510^{3}$} & \multirow[t]{2}{*}{$1.2610^{4}$} & $4.7310^{2}$ & \multirow[t]{3}{*}{$3.910^{3}$} \\
\hline & & 9 & & & 9 & & & 9 & & & 9 & \\
\hline $\mathbf{X}^{2}$ & & 9.33 & & & 7.85 & & & 7.22 & & & 3.32 & \\
\hline $\mathbf{p}$ & & $<0,01$ & & & $<0,01$ & & & $<0,05$ & . & & NS & \\
\hline
\end{tabular}




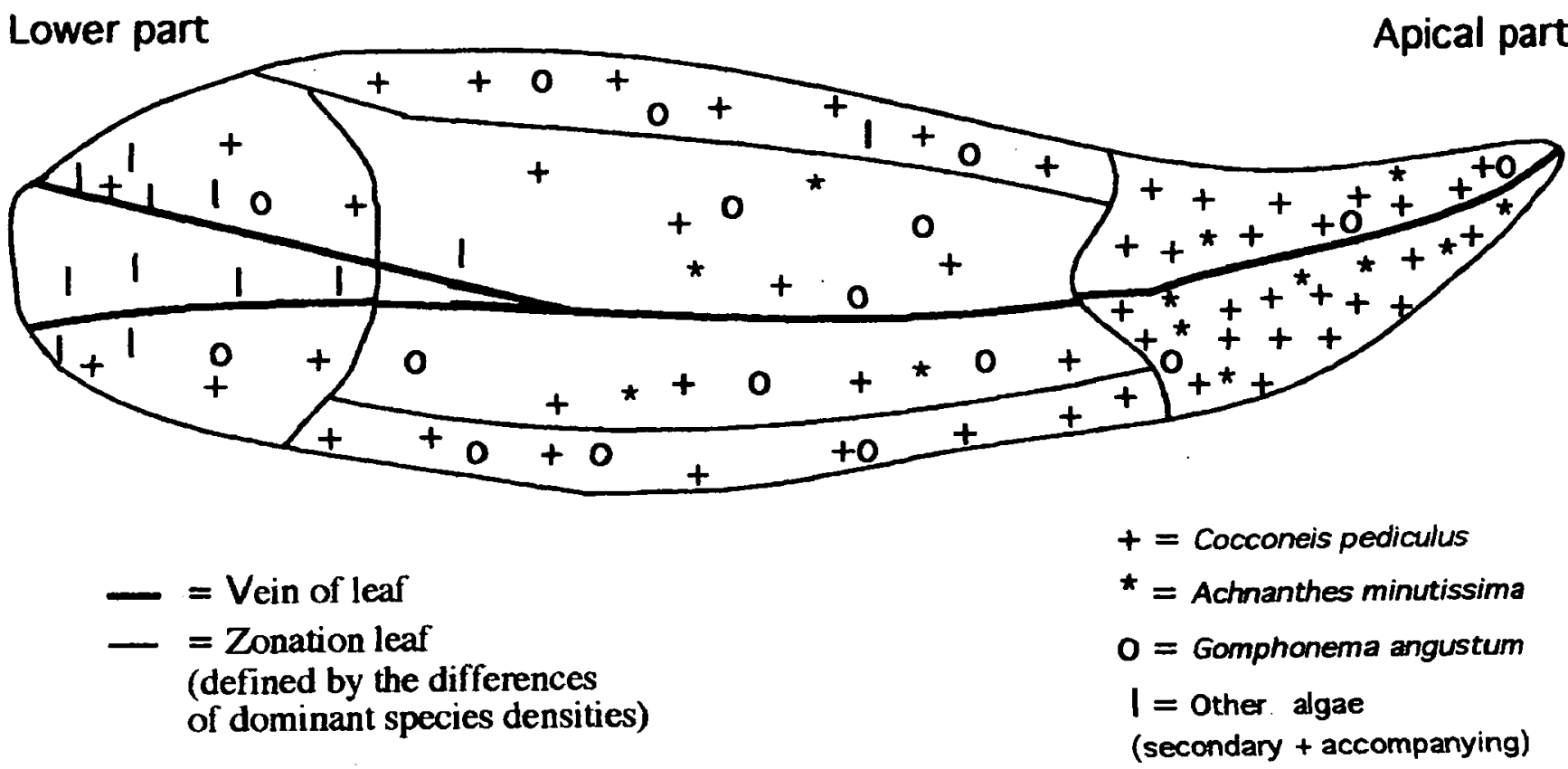

Fig. 3. Distribution of main epiphytic diatom species and «other algae» group on the upperside of Potamogeton densus leaves.

Fig. 3. Distribution des principales espèces de diatomées et des «autres algues» sur la face supérieure des feuilles de Potamogeton densus.

inhabiting several macrophytes exposed to the same environmental conditions vary considerably from one plant to another (Table 3).

Large qualitative and quantitative variations were observed between Chara and Cladophora. The prevailing species were different (Table 2) and the floristic procession diverse (Tables 2,3 ), despite the fact that they were collected at the same location under similar environmental conditions.

These between-plant diversity may not be correlated with abiotic parameters such as light, since the maximum algal density is found on the deepest part of the plant in the water column for Potamogeton $(90 \mathrm{~cm})$ and paradoxically on the surface leaves for Chara.

However, the distribution and density of the algae seem to be directly influenced by plant morphology and mineral content of plants which can play a decisive role in the process of algal distribution (Allen \& Ocevski 1981, Cattaneo \& Kalff 1980, Gregg \& Rose 1982, Lalonde \& Downing 1991).

Chara vulgaris presents many asperities formed by limestone deposits ; whereas the leaves of Potamogeton densus have a very low $\mathrm{Ca}^{++}$content, and their edges are finely wrought with many veins and denticles. Cladophora has a smooth aspect due to the alginates of which its cells are largely composed. The chemical composition of Chara differs considerably from that of the two other studied macrophytes : the calcium salt levels present in its walls is responsible for their stiffness, especially at the internodes. Calcite accounts for up to $70 \%$ of the total dry weight of these algae (Bernatowitz 1969). These chalky deposits give rise to marked protuberances at the internodes and verticals and seem to directly affect the composition and distribution of the algal populations. The large chalky incrustations reduce the flat surface areas available, while at the same time they increase the total living space because of the numerous intricate niches they provide. The species which require little anchorage space, such as those having mucous stalks among Gomphonema sp. and Rhoicosphenia abbreviata, are thus favoured to the detriment of those with large anchoring requirements, which will not find sufficient place to settle. The increase of available space will also no doubt have impact on the density of the colonizing algae, which was greater in the case of Chara.

As for Potamogeton, the flat morphology of its leaves could suffice to explain the complete prevailing of the algae Cocconeis pediculus which has large anchoring requirements. Indeed the concave shape of the hypovalve of this species makes it perfectly adapted to the circular filaments of Cladophora, and probably stands for its great abundance within the macroalgae.

Morphological differences between the host plants may contribute to the natural selection of colonizing species, depending on their mode of fixation, and thus 
Table 4. Within-plant homogeneity : mean cell densities (no.of cells $/ \mathrm{cm}^{2}$ ), standard deviations and coefficient of variation belonging to the 3 algal groups : dominant, secondary and accompanying species, obtained on 3 segments $(A, B, C)$ belonging to each of the 3 macrophytes. Data analysed using the Friedman test ( NS = differences not significant at $\mathrm{p}>0.05$ ).

Tableau 4. Homogénéité intra-plante : moyenne des densités cellulaires (cell// $\mathrm{cm}^{2}$ ), écart-type et coefficient de variation des 3 catégories d'algues: espèces dominantes, secondaires et accompagnatrices relevées sur les 3 réplicats (A,B,C) de chaque macrophyte. Données obtenues par le test de Friedman (NS = Différence non significative, $\mathrm{p}>0.05$ ).

Chana valgaris

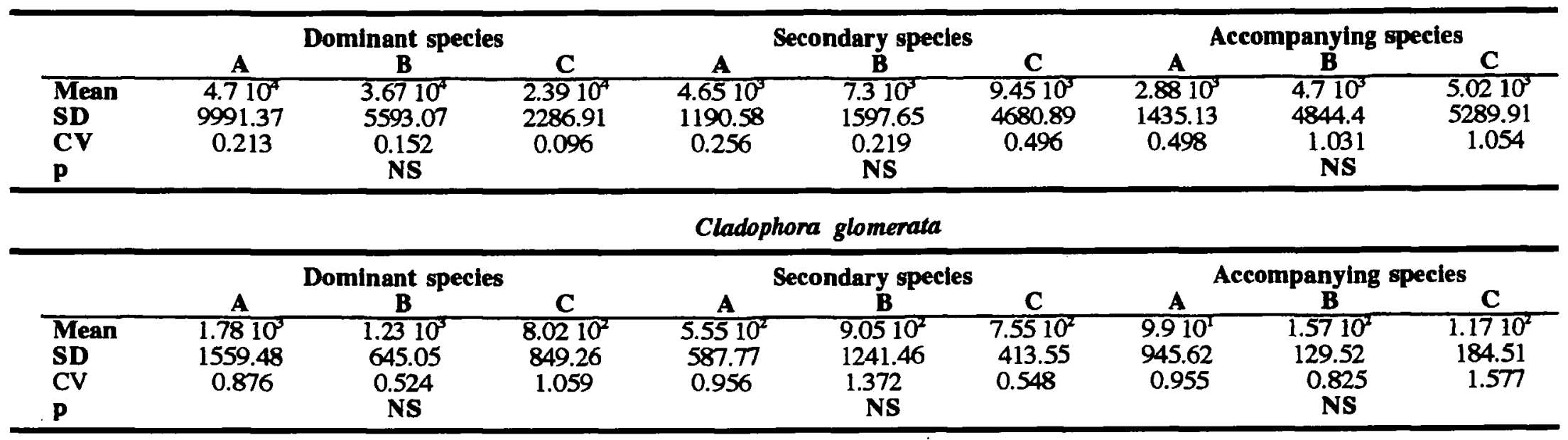

Potamogeton densus

\begin{tabular}{|c|c|c|c|c|c|c|c|c|c|}
\hline $\begin{array}{l}\text { Upper } \\
\text { side }\end{array}$ & \multicolumn{3}{|c|}{ Dominant species } & \multicolumn{3}{|c|}{ Secondary species } & \multicolumn{3}{|c|}{ Accompanying species } \\
\hline $\begin{array}{l}\text { Mean } \\
\text { SD } \\
\text { CV } \\
\text { p }\end{array}$ & $\begin{array}{c}\mathbf{A} \\
1.7510^{4} \\
3891.02 \\
0.222\end{array}$ & $\begin{array}{c}\text { B } \\
1.710^{4} \\
1475.63 \\
0.087 \\
\text { NS }\end{array}$ & $\begin{array}{c}\text { C } \\
1.6110^{4} \\
1901.97 \\
0.118\end{array}$ & $\begin{array}{c}\mathbf{A} \\
4.5510^{2} \\
119.41 \\
0.262\end{array}$ & $\begin{array}{c}\text { B } \\
6.0510^{2} \\
77.62 \\
0.128 \\
\text { NS }\end{array}$ & $\begin{array}{c}C \\
4.410^{2} \\
181.67 \\
0.413\end{array}$ & $\begin{array}{c}\mathbf{A} \\
5.0510^{2} \\
252.53 \\
0.5\end{array}$ & $\begin{array}{c}\text { B } \\
5.9910^{2} \\
119.55 \\
0.2 \\
\text { NS }\end{array}$ & $\begin{array}{c}\mathrm{C} \\
6.9610^{2} \\
166.35 \\
0.239\end{array}$ \\
\hline $\begin{array}{l}\text { Under } \\
\text { side }\end{array}$ & \multicolumn{3}{|c|}{ Dominant species } & \multicolumn{3}{|c|}{ Secondary speeles } & \multicolumn{3}{|c|}{ Accompanying specles } \\
\hline $\begin{array}{l}\text { Mean } \\
\text { SD } \\
\text { CV } \\
\text { p }\end{array}$ & $\begin{array}{c}\mathbf{A} \\
1.4910^{4} \\
2925.32 \\
0.196\end{array}$ & $\begin{array}{c}\text { B } \\
1.3610^{4} \\
1400 \\
0.103 \\
\text { NS }\end{array}$ & $\begin{array}{c}\text { C } \\
1.2410^{4} \\
5642.69 \\
0.455\end{array}$ & $\begin{array}{l}\frac{\mathbf{A}}{4.910^{2}} \\
31.225 \\
0.064\end{array}$ & $\begin{array}{c}\text { B } \\
3.5510^{2} \\
237.33 \\
0.669 \\
\text { NS }\end{array}$ & $\begin{array}{c}c \\
6.0510^{2} \\
430.32 \\
0.711\end{array}$ & $\begin{array}{c}\mathbf{A} \\
7.210^{2} \\
112.694 \\
0.157\end{array}$ & $\begin{array}{c}\text { B } \\
7.4510^{2} \\
199.27 \\
0.267 \\
\text { NS }\end{array}$ & $\begin{array}{c}\mathrm{C} \\
6.3510^{2} \\
544.68 \\
0.858\end{array}$ \\
\hline
\end{tabular}

favouring the homogeneous composition and structure of the epiphytic diatom communities within the plants, as shown by the low values of the coefficient of variation measured for these two macrophytes (Table 4).

Nevertheless, a pattern for epiphytic distribution on a leaf of Potamogeton, whatever its height on the plant, can be inferred. Indeed, specific parts of the leaf, such as the apical and peripheric borders, favour algal population, while the centre of the leaf remains devoid of microalgae (Fig. 3).

Apart from the shape of the plant, other parameters may influence the localization of the epiphyton. For example, the leaf is often thinner at borders and apex. Also, the gas exchanges and the release of nutrients are probably different among the total leaf surface of the plant, which could imply a specific distribution of the algae, as suggested by Allen 1971, Allanson 1973, Acs
\& Buczko 1994 and Burkholder \& Wetzel 1989, 1990. Last but not least, the grazing of the epiphyton by macroinvertebrates has to be taken into account (Jones 2000 , Power et al. 1985, Jones et al. 1998), especially when the surface of the macrophyte is flat and easy to reach (i.e. the leaves of Potamogeton).

Although this preliminary analysis does not permit to conclude on the impact of these two last parameters, it highlights the difficulty of a representative sampling, since the variations of algal population depend both on its environment and on its dynamic host.

\section{Acknowledgments}

The authors are particularly grateful to the French National Electricity Board (EDF) for giving access to the sites and would like to express their gratitude to the two anonymous reviewers for helpful comments. 


\section{References}

Acs E. \& Buczko K. 1994. - Daily changes of reed periphyton composition in a shallow Hungarian lake (Lake Velence). Proc. 13 Internat. Diatom Symp., Paris : 1-10.

Allanson B.R. 1973. - The fine structure of periphyton of Chara sp. and Potamogeton natans from Wytham Pond, Oxford, and its significance to the macrophyte-periphyton model of R.G. Wetzel and H.L.Allen. Freshwat. Biol., 3: 535-542.

Allen H. 1971. - Primary productivity, chemo-organotrophy, and nutritional interactions of epiphytic algae and bacteria on macrophytes in the littoral of a lake. Ecol. Monogr., $41: 97-127$.

Allen H. \& Ocevski B.T. 1981. — Comparative primary productivity of algal epiphytes on three species of macrophytes in the littoral zone of Lake Ohrid, Yugoslavia. Holarct. Ecol., 4 : 155-160.

Bernatowitz S.T. 1969. Macrophytes in the Lake Warnick and their chemical composition. Ekol. Pol. Ser. A, 17 (27) : 447-467.

Blindow I. 1987. - The composition and density of epiphyton on several species of submerged macrophytes- The neutral substrate hypothesis tested. Aquat. Bot., $29: 157-168$.

Burkholder J.M. \& Wetzel R.G. 1989. - Microbial colonization on natural and artificial macrophytes in a phosphorus-limited, hardwater lake. J. Phycol., $25: 55-65$.

Burkholder J.M. \& Wetzel R.G. 1990. — Epiphytic alkaline phosphatase on natural and artificial plants in an oligotrophic lake : reevaluation of the role of macrophytes as a phosphorus source for epiphytes. Limnol. Oceanogr., 35: 736-747.

Cattaneo A. \& Kalff J. 1978. - Seasonal changes in the epiphyte community of natural and artificial macrophytes in lake Memphremagog. Hydrobiologia, 60 : 135-144.

Cattaneo A. \& Kalff J. 1979. - Primary production of algae growing on natural and artificial aquatic plants : a study of interactions between epiphytes and their substrate. Limnol. Oceanogr., $24: 1031-1037$.

Cattaneo A. \& Kalff J. 1980. - The relative contribution of aquatic macrophytes and their epiphytes to the production of macrophyte beds. Limnol. Oceanogr., $25: 280-289$.

Comte K. 1996. - Approche méthodologique de l'épiphytisme en rivière méditerranéenne régulée (moyenne-Durance) : Séparation du complexe épiphyte/plante-hôte. Bioaccumulation des métaux lourds au sein des végétaux. DEA. Aix-Marseille III : 42p

Fayolle S. 1998. - Réponses des communautés végétales strictement aquatiques (algues et macrophytes) aux perturbations hydrodynamiques (débits réservés, restitutions) en Durance aménagée (sud-est de la France). Doctorat d'Université, Aix-Marseille III : $227 \mathrm{p}$.

Fayolle S., Cazaubon A., Comte K. \& Franquet E. 1998. - The intermediate disturbance Hypothesis : application of this concept to the response of epilithon in a regulated Mediterranean river (lower-Durance, Southeastern France). Arch. Hydrobiol., 143 : 57-77.

Fontaine T.D. \& Nigh D.G. 1983. - Characteristics of epiphytic communities on natural and artificial submersed lotic plants : substrate effects. Arch. Hydrobiol., $96: 293-301$.

Friedman A.R. 1954. - A distribution-free k-sample test against ordered alternatives. Biometrika, 41 : 133-145.

Goldsborough L.G., Robinson G.G.C. \& Gurney S.E. 1986. - An enclosure/substratum system for in situ ecological studies of periphyton. Arch. Hydrobiol., $96: 293-301$.

Gregg W.W. \& Rose F.L. 1982. - The effects of aquatic macrophytes on the stream microenvironment. Aquat. Bot., 14 : 309-324.
Harlin M. 1973. - Transfer of products between epiphytic marine algae and host plants. J. Phycol., $9: 243-248$.

Holmes N. T. H. \& Whitton B. A. 1977. - The macrophytic vegetation of the river Tees in $1975:$ observed and predicted changes. Freshwat. Biol., 7 : 43-60.

Jones M.R., Weatherhead M., Stanger C., \& Graynoth E. 1998. Macroinvertebrate distribution in the littoral zone of Lake Coleridge, South Island, New Zealand- effects of habitat stability, wind exposure and macrophytes. New Zealand J. Mar. Freswat. Res., 32 : 287-305.

Jones J.I., Moss B., Eaton J.W. \& Young J.O. 2000. — Do submerged aquatic plants influence periphyton community composition for the benefit of invertebrate mutualists ? Freshwat. Biol., 43 : 591-604.

Kelly M.G., Cazaubon A., Coring E., Dell'Uomo L., Ector A., Goldsmith B., Guasch H., Hürlimann J., Jarlman A., Kaweka B., Kwandrans J., Laugaste R., Lindstrom E.A., Leitao M., Marvan P., Padisak J., Pipp E., Prygiel J., Rott E., Sabater S., Van Dam H., Vizinet J. 1998. - Recommendations for the routine sampling of diatoms for water quality assessments in Europe. J. Appl. Phycol., $10(2): 15-224$.

Krammer K. \& Lange-Bertalot H. 1986. - Bacillariophyceae 1 : Naviculaceae. - Süßwasserflora von Mitteleuropa, H. Ettl, J. Gerloff, H. Heynig \& D. Mollenhauer (eds.) ; Band $2 /$ : G. Fisher Verlag Stuttgart : $876 \mathrm{p}$.

Krammer K. \& Lange-Bertalot H. 1988. - Bacillariophyceae 2 : Bacillariaceae, Epithemiaceae, Surirellaceae. - Süßwasserflora von Mitteleuropa, H. Ettl, J. Gerloff, H. Heynig \& D. Mollenhauer (eds.) ; Band 2/2 : G. Fisher Verlag Stuttgart : 596 p.

Krammer K. \& Lange-Bertalot H. 1991a. - Bacillariophyceae 3 : Centrales, Fragilariaceae, Eunotiaceae. - Süßwasserflora von Mitteleuropa, H. Ettl, J. Gerloff, H. Heynig \& D. Mollenhauer (eds.) ; Band $2 / 3:$ G. Fisher Verlag Stuttgart : 600 p.

Krammer K. \& Lange-Bertalot H. 1991b. - Bacillariophyceae 4 : Achnanthaceae. Kritische Ergänzungen zu Navicula (Lineolatae) und Gomphonema. - Süßwasserflora von Mitteleuropa, H. Ettl, J. Gerloff, H. Heynig \& D. Mollenhauer (eds.) ; Band 2/4 : G. Fisher Verlag Stuttgart : $437 \mathrm{p}$.

Lalonde S. \& Downing J.A. 1991. - Epiphyton biomass is related to Lake Trophic Status, depth, and macrophyte architecture. Can. J. Fish. Aquat. Sci., $48: 2285-2291$.

Lenoir A. \& Coste M. 1994. - Estimation de la qualité des eaux du bassin Rhin Meuse à l'aide des communautés des diatomées benthiques. Cemagref de Bordeaux. Agence de l'eau Rhin Meuse.

Millie D.F. \& Lowe R.L. 1983. - Studies on Lake Erie's littoral algae : host specificity and temporal periodicity of epiphytic diatoms. Hydrobiologia, $99: 7-18$.

Morin J. 1986. - Initial colonization of periphyton on natural and artificial apices of Myriophyllum heterophyllum Michx. Freshwat. Biol., $16: 685-694$.

Power M.E., Matthews V.J., \& Stewart A.J. 1985. - Grazing minnows, piscivorous bass and stream algae : dynamics of a strong interaction. Ecology, 66 : 1448-1456.

Round F.E. 1981. - The Ecology of Algae. University Press, Cambridge : $595 \mathrm{p}$.

Snoeijs P. 1994. - Distribution of epiphytic diatom species composition, diversity and biomass on different macroalgal hosts along seasonal and salinity gradients in the Baltic sea. Diatom Res., 9 (1) : 189-211.

Wetzel R.G. 1983. - Limnology. 2nd ed. Saunders College Publ., New York : $767 \mathrm{p}$. 